\title{
HPV in squamous cell carcinoma: An Immuno-histochemical study
}

\author{
Diar G. Aziz, Bedoor A.K. Al-Irhayim \\ From the Department of Pathology, College of Medicine, University of Mosul. \\ Correspondence: Diar G. Aziz. Department of Pathology, College of Medicine, University of Mosul, Mosul, Iraq. \\ Email: drdiaraziz@yahoo.com.
}

(Ann. Coll. Med. Mosul 2013; 39 (1): 19-24).

Received: $29^{\text {th }}$ Nov. 2011; Accepted: $2^{\text {nd }}$ Oct. 2012.

\section{ABSTRACT}

Objectives: This study is performed to evaluate the immune-expression of human papillomavirus (HPV) in a series of 100 samples of squamous cell carcinoma (SCC) from different sites of the body and to correlate it with anatomical site and grade of the tumor, age and sex of the patients, grade of tumor and to compare our results with those of other studies.

Patients and methods: There were 100 patients with primary SCC from larynx, cervix, oral cavity and skin. Samples were obtained in a pro and retrospective fashion from teaching hospitals and private laboratories in Mosul. During a period of seven months from July 2009 through January 2010. Immunoexpression assay was performed using immunohistochemically (IHC).

Results: The patients' age ranged between 15 and 90 years, with a mean of 51.28 year. There were 62 males and 38 females. Only nine of the hundred cases were positive for HPV, 3 out of 45 cases of laryngeal SCC were positive (6.67\%) and 22 of oral cavity SCC cases were positive (27.27\%). All of the 23 cervical and the 10 skin cases were negative for HPV. HPV expression was significantly correlated with the primary anatomical site but not with the age and sex of the patients in laryngeal and oral cavity SCC.

Conclusions: 1.) HPV was expressed in nine out of 100 cases of SCC, adopting immunohistochemistry (IHC) for its detection, six of the cases were in the oral cavity and three were in the larynx with none from cervix or skin. 2.) In the positive cases the only significant correlations were with the anatomical site and in relation to grade in the larynx. 3.) Our results are low when compared to more sensitive methods for HPV detection like Polymerase Chain Reaction (PCR), Southern Blot Hybridization (SBH) and In Situ Hybridization (ISH); however this may also be attributed to the relatively small number of cases and to the possibility that our cases of SCC are not HPV related.

\section{دراسة مناعية نسيجية كيمائية للتحري عن فيروس ورم الحليمات البشري في سرطانات الخلايا الصرشفية}

الأهداف: أجريت هذه الدراسة لتقييم حالة الظهور المناعي لفيروس ورم الحليمات البشري في . . 1 حالة من سرطان الخلايا

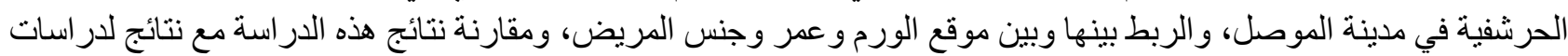

الحالات والطرق: ان هذه الدر اسة مستقبلية ورجعية، وتم من خلالها تجميع . 1 حالة من سرطان الخلايا الحرشفية من الحنجرة،

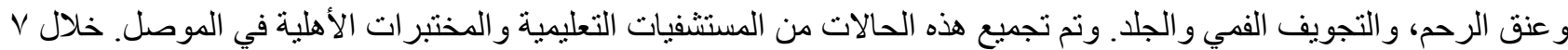

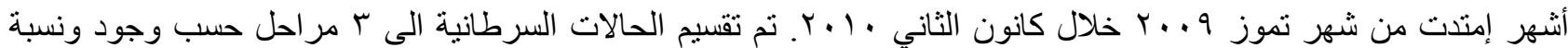
تكون الكير اتين ووجود الجسور الخلوية. لقد تم التحري عن فيروس ورم الحليمات البشري بطريقة مناعية_نسيجية_كيميائية باستخدام المضاد الاولي (المضاد أحادي

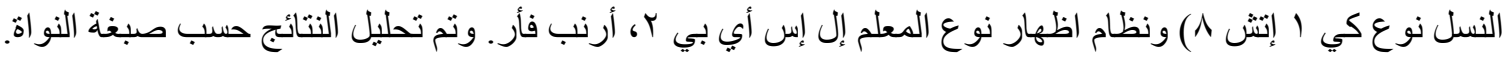

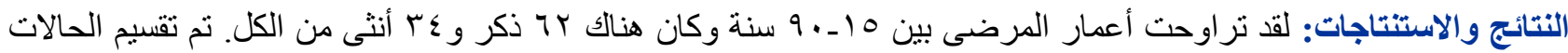
حسب موقع المرض الى سرطان الخلايا الحرشفية في الحنجرة 0ـ ثلاث كانت ايجابية، التجويف الفمي ب ب حالة ستة منها ايجابية،

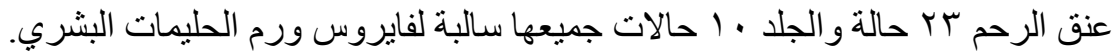


$\mathrm{H}$ $\mathrm{PV}$ is regarded as the most significant risk factor for cervical carcinoma ${ }^{(1)}$, however HPV alone is not sufficient to cause dysplasia and factors like smoking and immune suppression are required as co-agents ${ }^{(2)}$. In the oral cavity HPV16seropositive smokers had an approximately 15 -fold increase risk of SCC ${ }^{(1)}$, while the frequency of HPV infection in laryngeal SCC varies widely (3\%$85 \%$ ) among different studies depending on the detection technique ${ }^{(3-5)}$. In addition papillomaviruses can cause skin cancer ${ }^{(6)}$. Our aims of the present study are 1.) Evaluating and comparing HPV expression in hundred cases of SCC from larynx, cervix, oral cavity and skin adopting immunohistochemical method for its detection. 2.) Finding out any relationship between HPV expression and some clinico pathologic parameters. 3.) Comparing our results with other studies.

\section{PATIENTS AND METHODS}

This study was based on samples prospectively and retrospectively collected from hundred patients with primary SCC from larynx, oral cavity, cervix and skin. Samples were obtained from teaching hospital and private laboratories in Mosul. Expression of HPV antigen was assessed by immunohistochemical staining and the results were compared in relation to the anatomical site of the tumor and the age and sex of patients which were obtained from their request form.

Hematoxylin and eosin ( $H$ \& E) stained slides from formalin-fixed paraffin-embedded biopsy blocks were reevaluated to verify the presence of SCC and to grade the tumor. The tumors were classified into 3 grades according to the degree of cellular keratinization and the presence of intercellular bridges into well, moderately and poorly differentiated.

HPV expression was assessed immunohistochemically on formalin-fixed paraffin-embedded tissues of the tumor, using mouse monoclonal antibody (clone $\mathrm{K} 1 \mathrm{H} 8$ ), RTU (DAKO, Carpintera, $\mathrm{Ca}$, USA) and LSAB2 System-HRP.

Positive and negative control slides were involved in each run of staining. Positive control slides were prepared from condyloma accuminata known to be positive for HPV. While negative control slides were prepared from the same tissue block, but incubated with Dako Universal Negative Control Rabbit (code N1699) instead of the primary antibody.

Positive immunostaining was largely confined to the nuclei of infected cells. Occasionally the cytoplasm of koilocytotic cells was observed to be immunoreactive ${ }^{(6)}$.

\section{Statistical analysis}

The relationship between HPV expression and the clinico-pathologic variables was analyzed by the Fisher Freeman Holton's and Fisher's exact test. The results were considered statistically significant if the $p$ value was $\leq 0.05$.

\section{RESULTS}

During a period of 7 months (from July 2009 through January 2010), immunohistochemical study to assess the presence of HPV in 100 biopsy specimens from patients with primary SCC was performed. There were 62 males and 38 females. The male: female ratio was $1.6: 1$ (Table 1 ). The patients' age ranged between 15 and 90 years, with a mean of 51.28 year. Out of the hundred cases of SCC, nine were positive for HPV. Three out of 45 cases of laryngeal SCC samples were positive $(6.67 \%)$, two males in their seventh decade and a female in the fourth decade. Six out of 22 oral cavity SCC samples were positive for HPV (27.27\%) three males and three females, 3 in their fourth decade, 2 in their sixth decade and 1 in the fifth decade. All the 23 cervical SCC and the 10 SCC of skin were negative for HPV.

A statistically significant correlation was found between HPV expression and the anatomical site of SCC ( $P$ value $\leq 0.05$ ) (Table 2). It was highest in oral cavity SCC while cervical and cutaneous SCC failed to demonstrate any positivity. Statistically, no significant correlation was found between HPV expression and patients' age and sex in both laryngeal and oral cavity SCC (Table 2). No significant correlation was found between tumor grade and HPV expression in oral cavity SCC, but significant correlation was found in laryngeal SCC with grade. Figures (1\&2) are microphotographs of IHC of HPV. 
Table 1. Sex distribution of patients with SCC in relation to site and HPV status.

\begin{tabular}{|l|c|c|c|c|c|c|c|}
\hline \multirow{2}{*}{} & \multicolumn{2}{|c|}{ Total } & \multicolumn{2}{c|}{ HPV status +ve } & \multicolumn{2}{c|}{ HPV status -ve } & \multirow{2}{*}{ p-value } \\
\cline { 2 - 8 } & No. & $\%$ & No. & $\%$ & No. & $\%$ & \\
\hline Larynx SCC & 45 & & 3 & 6.67 & 42 & 93.33 & \\
\hline Male & 38 & 84.44 & 2 & 66.67 & 36 & 85.71 & 0.1289 \\
\hline Female & 7 & 15.56 & 1 & 33.33 & 6 & 14.28 & N.S \\
\hline Oral cavity SCC & 22 & & 6 & & 16 & & 75 \\
\hline Male & 15 & 68.18 & 3 & 50 & 12 & 0.1266 \\
\hline Female & 7 & 31.82 & 3 & 50 & 4 & 25 & N.S \\
\hline
\end{tabular}

N.S: not significant.

Table 2. HPV status according to primary anatomical site.

\begin{tabular}{|c|c|c|c|c|c|c|c|}
\hline \multirow[t]{2}{*}{ Site } & \multicolumn{2}{|c|}{ Total } & \multicolumn{2}{|c|}{$\begin{array}{c}\text { HPV } \\
\text { status +ve }\end{array}$} & \multicolumn{2}{|c|}{$\begin{array}{c}\text { HPV } \\
\text { status -ve }\end{array}$} & \multirow[t]{2}{*}{ p-value } \\
\hline & No. & $\%$ & No. & $\%$ & No. & $\%$ & \\
\hline Larynx & 45 & 45 & 3 & 33.3 & 42 & 46.1 & \\
\hline Cervix & 23 & 23 & 0 & 0.0 & 23 & 25.3 & \multirow{4}{*}{$\begin{array}{c}0.02615 \\
\mathrm{~S}\end{array}$} \\
\hline $\begin{array}{l}\text { Oral } \\
\text { cavity }\end{array}$ & 22 & 22 & 6 & 66.7 & 16 & 17.6 & \\
\hline Skin & 10 & 10 & 0 & 0.0 & 10 & 11 & \\
\hline Total & 100 & 100 & 9 & 100 & 91 & 100 & \\
\hline
\end{tabular}

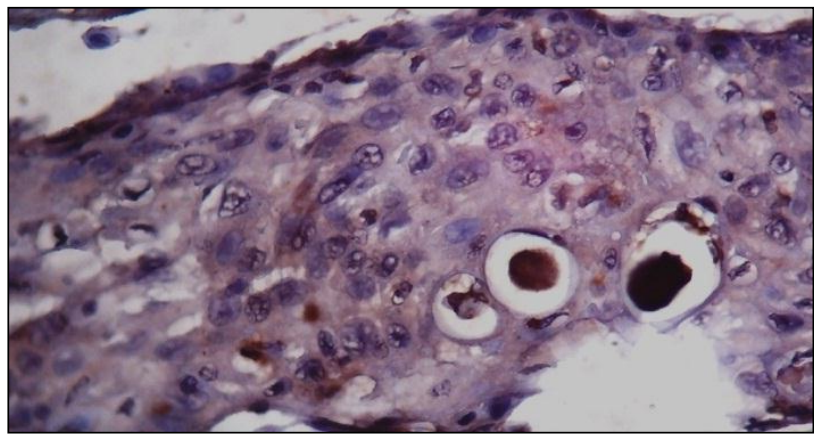

Figure 1. Moderately differentiated oral cavity SCC IHC for HPV positive $(\times 400)$.

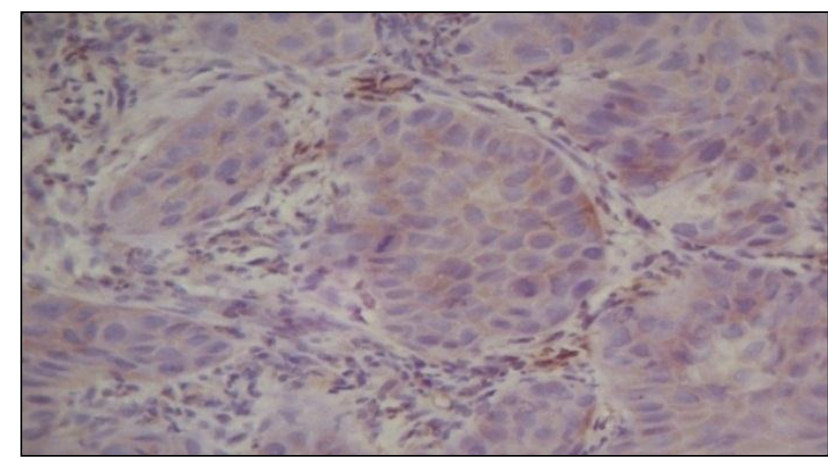

Figure 2. Moderately differentiated oral cavity SCC IHC for HPV negative $(\times 400)$.

\section{DISCUSSION}

The close relationship between HPV and SCC has long been suspected and investigated. In recent years, the decline in the mortality from cervical cancer following the immunization of young girls in the USA against HPV, has made this association more evident and dramatically increased the interest in establishing the link between the two.

Various studies have reported a wide range of positive values of HPV in various sites of the body $(3,4)$. This wide range can be related to the number of cases examined, detection technique, as well as the site of the tumor and the tissue sample used ${ }^{(3 \text {, }}$ 4). Also differences in population groups and diversity of risk habits may contribute to the wide range of prevalence reported ${ }^{(7) \text {. }}$

In the current study IHC was used to demonstrate HPV in 100 cases of SCC from cervix, larynx, oral cavity and skin in Mosul; it was found in $9 \%$ of the cases. To the best of our knowledge there has been no previous HPV related study from Mosul.

None of the 23 cases with cervical SCC were positive for HPV expression. This may be attributed to the high specifity of $\mathrm{IHC}$ or to the possibility that our cases of SCC are not HPV related. Unfortunately, even at the WHO HPV information centre, there was no available data correlating HPV with cervical cancer in Iraq or even in Western Asia ${ }^{(8)}$. However WHO reports $70.9 \%$ prevalence of HPV in the cervical cancer in the World ${ }^{(8)}$. Alves et al ${ }^{(9)}$ reports lower percentage of HPV expression in cervical intraepithelial neoplasia using IHC $(28.2 \%$ of the cases) than the percentage reported using the Non-isotopic In Situ Hybridization (NISH) (43.6 \%of the cases) ${ }^{(9)}$.

In this study HPV was observed in $6.7 \%$ of laryngeal $\mathrm{SCC}$, fitting within the wide range reported by other studies as compared to them in Table I. There was no significant correlation between HPV and age and sex of the patients but 
significant correlation with grade. This is consistent with the results of the studies of Gillison et al ${ }^{(10)}$ and Pazil et al ${ }^{(11)}$.

In our study HPV expression was found in $27.27 \%$ of SCC of oral cavity. These results are within the wide range reported by other studies Table II. No significant correlation was found between HPV status and sex and age, a finding consistent with the studies of Ringström et al ${ }^{(12)}$, Portugal et al ${ }^{(13)}$ and Soares et al ${ }^{(14)}$ but not with the study of Cruz et al ${ }^{(15)}$ which showed significant association between HPV presence and the age of patients ${ }^{(15)}$. No significant correlation was found between HPV status and grade of the tumor which is consistent with the study of Kumar et al ${ }^{(16)}$.

None of the ten cases of SCC of skin were positive for HPV. However other studies using Southern hybridization, sensitive enough to detect one copy of HPV genome per cell, has seldom been successful in demonstrating HPV sequences in premalignant and malignant lesions of the skin of immunocompetent or immunosuppressed patients ${ }^{(17)}$. Using more sensitive techniques various studies report a range of HPV DNA sequences in non-melanoma skin cancer in immunocompetent individuals $(25 \%-55 \%)^{(17)}$.

Table I. Laryngeal SCC/ HPV expression: comparative table.

\begin{tabular}{|c|c|c|c|c|c|}
\hline Study & Year & Country/town & Detection method & $\begin{array}{l}\text { No. of cancer } \\
\text { cases }\end{array}$ & $\begin{array}{l}\% \text { of HPV } \\
+ \text { ve cases }\end{array}$ \\
\hline Current study & 2010 & Mosul & $\mathrm{IHC}$ & 45 & 6.7 \\
\hline Holzinger et al ${ }^{(18)}$ & 2009 & Germany & $\begin{array}{c}\text { Multiplex Papillomavirus } \\
\text { Genotyping MPG }\end{array}$ & 94 & 24 \\
\hline Morshed et al ${ }^{(19)}$ & 2005 & Poland & $\mathrm{IHC}$ & 40 & 15 \\
\hline Kaya et al ${ }^{(3)}$ & 2001 & Turkey & $\mathrm{NISH}$ & 21 & 47 \\
\hline Jacob et al ${ }^{(4)}$ & 2001 & India & PCR & 9 & 34.1 \\
\hline Gillison et al ${ }^{(10)}$ & 2000 & Oxford & PCR ISH SBH & 86 & 18.6 \\
\hline Lindeberg et al ${ }^{(6)}$ & 1999 & Denmark & PCR & 30 & 3.3 \\
\hline PAZ I et al ${ }^{(11)}$ & 1997 & California & PCR & 49 & 8.16 \\
\hline Shen et al ${ }^{(20)}$ & 1996 & USA & PCR & 32 & 9.4 \\
\hline
\end{tabular}

Table II. Oral cavity SCC HPV expression: comparative table.

\begin{tabular}{|c|c|c|c|c|c|}
\hline Study & Year & Country/town & Detection method & $\begin{array}{l}\text { No. of cancer } \\
\text { cases }\end{array}$ & $\begin{array}{l}\% \text { of HPV } \\
+ \text { ve cases }\end{array}$ \\
\hline Current study & 2010 & Mosul & $\mathrm{IHC}$ & 22 & 27.27 \\
\hline Kies et $\mathrm{al}^{(21)}$ & 2010 & USA & PCR & 26 & 46 \\
\hline Straetman et al ${ }^{(22)}$ & 2009 & Netherland & $\begin{array}{c}\text { PCR and FISH } \\
\text { (Fluorescence ISH) }\end{array}$ & 81 & 41 \\
\hline Holzinge et al ${ }^{(18)}$ & 2009 & Germany & MPG & 208 & 48 \\
\hline $\mathrm{D}^{\prime}$ Souza et $\mathrm{al}^{(23)}$ & 2007 & Germany & PCR & 100 & 72 \\
\hline Soares et al ${ }^{(14)}$ & 2007 & Brazil & PCR & 75 & 24 \\
\hline Syrj’anen et al ${ }^{(24)}$ & 2005 & $\begin{array}{c}\text { meta-analyses of } \\
\text { studies at multi-centre }\end{array}$ & any & 4768 & 22 \\
\hline Shimizu et al ${ }^{(25)}$ & 2004 & Japan & PCR & 27 & 18 \\
\hline Yang et al (26) & 2004 & Taiwan & PCR & 37 & 10.8 \\
\hline Herrero et $\mathrm{al}^{(2 /)}$ & 2003 & IARC Multicenter & PCR & 1670 & 22.2 \\
\hline Kumar et $^{(16)}$ & 2003 & India & $\mathrm{ISH}$ & 42 & 31 \\
\hline Ringström et al ${ }^{(12)}$ & 2002 & Boston & PCR & 89 & 20 \\
\hline Gillison et $\mathrm{al}^{(10)}$ & 2000 & Oxford & PCR ISH SBH & 167 & 9.3 \\
\hline \multirow{3}{*}{ Miller et $\mathrm{al}^{(7)}$} & \multirow{3}{*}{1995} & \multirow{3}{*}{$\begin{array}{l}\text { retrospective review of } \\
\text { the literature }\end{array}$} & PCR & 329 & 37.1 \\
\hline & & & $\mathrm{SBH}$ & 334 & 25.2 \\
\hline & & & $\mathrm{IHC}, \mathrm{ISH}$ & 362 & 16.9 \\
\hline
\end{tabular}


The major obstacle in establishing the presence of HPV with certainty is choosing a detection method that is sensitive and specific. IHC, according to literature, is a specific method for detecting HPV in paraffin embedded tissue, however it lacks the sensitivity hence probably is the low number of positive cases in our study. Although PCR is highly sensitive technique it can lead to the detection of the latent infection which is etiologically unrelated to the tumor. In contrast, ISH is less sensitive but recognize SCC which is etiologically linked to HPV infection.

\section{CONCLUSIONS}

HPV was expressed in nine out of 100 cases of SCC, adopting IHC for its detection, six of the cases were in the oral cavity and three were in the larynx with none from cervix or skin.

In the positive cases the only significant correlations were with the anatomical site and the grade in the larynx.

Our results are low when compared to more sensitive methods for HPV detection like PCR, $\mathrm{SBH}, \mathrm{ISH}$, however this may also be attributed to the relatively small number of cases and to the possibility that our cases of SCC are not HPV related.

\section{REFERENCES}

1. Queiroz C, Silva TC, Alves VAF, et al. P16 ${ }^{\text {INK4a }}$ expression as a potential prognostic marker in cervical pre-neoplastic and neoplastic lesions. Pathology 2005;202: 77-83.

2. Monga A. Gynaecolgy by Ten Teachers, $18^{\text {th }}$ edition, Edward Arnold Ltd, 2006.p.131-136.

3. Kaya H, Kotiloglu E, Inanli S, et al. Prevalence of human papillomavirus (HPV) DNA in larynx and lung carcinomas. Pathologica 2001; 93: 531-534.

4. Jacob SE, Sreevidya S, Chacko E, et al. Cellular manifestations of human papillomavirus infection in laryngeal tissues. J Surg Oncol 2002; 79:142-150.

5. Lindeberg $H$, Krogdahl A. Laryngeal cancer and human papillomavirus: HPV is absent in the majority of laryngeal carcinomas. Cancer Lett 1999;146: 9-13.

6. Erdmann J. Recent Studies Attempt to Clarify Relationship Between Oral Cancer and Human Papillomavirus. Journal of the National Cancer Institute 2003; 95(9):638-639.

7. Termine N, Panzarella V, Falaschini S, et al. HPV in oral squamous cell carcinoma vs head and neck squamous cell carcinoma biopsies: a meta-analysis (1988-2007). Annals of Oncology 2008 19(10):16811690.
8. World Health Organization. WHO/ICO Information Centre on HPV and Cervical Cancer. Available from: URL: http://www.who.int/hpvcentre/en.

9. Alves VAF, Wakamatsu A, Santos RTM, High-Risk Papilloma Virus Capsid Protein (L1) - Immunohistochemistry and Potential Use In Clinical Practice. J. Bras. Ginecol. 1988; 98: 257 - 261.

10. Gillison ML, Koch WM, Capone RB, et al. Evidence for a Causal Association between Human Papillomavirus and a Subset of Head and Neck. J Natl Cancer Inst 2000; 92:709-20.

11. Pazil B, Cook N, Odom-Maryon $T$, et al. Human papillomavirus (HPV) in head and neck cancer: An association of HPV 16 with squamous cell carcinoma of Waldeyer's tonsillar ring. Cancer 1997; 79: 595-604.

12. Ringström E, Peters E, Hasegawa M, et al. Human Papillomavirus Type 16 and Squamous Cell Carcinoma of the Head and Neck. Clinical Cancer Research 2002; 8: $3187-3192$.

13. Portugal LG, Goldenberg JD, Wenig BL, et al. Human Papillomavirus Expression and p53 Gene Mutations in Squamous Cell Carcinoma. Arch Otolaryngol Head Neck Surg 1997;123(11):1230-1234.

14. Soares $R C$, Oliveira $M C$, Souza $L B$, et al. Human papillomavirus in oral squamous cells carcinoma in a population of 75 Brazilian patients. American Journal of Otolaryngology 2007; 28(6): 397-400.

15. Cruz IBF, Snijders PJF, Steenbergen RDM, et al. Age-dependence of humanpapillomavirus DNA presence in oral squamous cell carcinomas European Journal Part B: Oral Oncology1996; 32(1):55-62.

16. Kumar RV, Kadkol SS, Daniel R, et al. Human papillomavirus, p53 and Cyclin D1 expression in oropharyngeal carcinoma. International Journal of Oral and Maxillofacial Surgery 2003; 32(5): 539-543.

17. Orth G. Human Papillomaviruses and the Skin: More to be Learned. Journal of Investigative Dermatology 2004; 123: xi-xiii.

18. Holzinger D, Halec G, Schmitt M, et al. Molecular characterization of HPV16-associated squamous cell carcinomas of the oropharynx and larynx. Oral Oncology Supplement 2009; 3:122.

19. Morshed K, Korobowicz E, Szyman' ski M, et al. Immunohistochemical demonstration of multiple HPV types in laryngealsquamous cell carcinoma. Eur Arch Otorhinolaryngol 2005; 262: 917-920

20. Shen J, Tate JE, Crum CP, et al. Prevalence of human papillomaviruses (HPV) in benign and malignant tumors of the upper respiratory tract. Mod Pathol. 1996; 9(1):15-20.

21. Kies MS, Holsinger FC, Lee JJ, et al. Induction chemotherapy and cetuximab for locally advanced squamous cell carcinoma of the head and neck: results from a phase II prospective trial. J Clin Oncol. 2010;28(1):8-14. 
22. Straetmans JMJAA, Olthof N, Vos I, et al. Prognostic squamous cell carcinomas. Oral Oncology Supplement 2009; 3(1):122.

23. D'Souza G, Kreimer AR, Viscidi R, et al. CaseControl Study of Human Papillomavirus and Oropharyngeal Cancer. The New England Journal of Medicine 2007; 356:1944-1956.

24. Syrj"anen S. Human papillomavirus (HPV) in head and neck cancer. Journal of Clinical Virology 2005;32S: S59-S66.

25. Shimizu M, Adachi A, Zheng S, et al. Detection of various types of human papillomavirus DNA, mainly value of HPV and cervical metastasis in oropharyngeal belonging to the cutaneous-group, more frequently in normal tissue than in squamous cell carcinomas of the lip. Journal of Dermatological Science 2004; 36, 33-39.

26. Yang $Y$ Y, Koh L-W. Involvement of Viral and Chemical Factors with Oral Cancer in Taiwan Jpn. J Clin Oncol 2004;34(4):176-183.

27. Herrero R, Castellsagué $X$, Pawlita $M$, et al. Human Papillomavirus and Oral Cancer: The International Agency for Research on Cancer Multicenter Study. Journal of the National Cancer Institute 2003, 95(23): $1772-1783$ 